JPSCR: Journal of Pharmaceutical Science and Clinical Research, 2021, 01, 49-61

DOI: 10.20961/jpscr.v6i1.39357

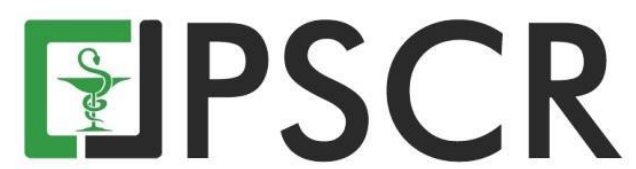

\title{
Evaluasi Performa Supply Chain Management Pedagang Besar Farmasi Terhadap Proses Pengadaan Di Apotek Kimia Farma Unit Bisnis Sidoarjo
}

\author{
Valiandri Puspadina ${ }^{*}$, Oetari Oetari² dan Gunawan Pamudji Widodo \\ ${ }^{1}$ Program Studi S2 Ilmu Farmasi Universitas Setia Budi, JL. Letjen. Sutoyo, Jebres, Surakarta, Jawa Tengah, \\ Indonesia, 57127 \\ ${ }^{2}$ Fakultas Farmasi Universitas Setia Budi, JL. Letjen. Sutoyo, Jebres, Surakarta, Jawa Tengah, Indonesia, 57127 \\ *email korespondensi : valiandri12@gmail.com
}

Received 22 January 2020, Accepted 14 December 2020, Published 15 March 2021

\begin{abstract}
Abstrak: Terjadinya pergeseran paradigma pelayanan kefarmasian dari pelayanan obat (drug oriented) menjadi lebih berfokus kepada pelayanan pasien (patient oriented) dengan berdasar kepada Pharmaceutical Care saat ini sedang terjadi dengan tetap mengkedepankan pedoman patient safety. Salah satu penunjang tercapainya patient safety adalah ketersediaan obat yang dipengaruhi oleh prosess supply chain dari pihak distributor kepada apotek. Tujuan dilakukannya penelitian ini adalah untuk mengetahui performa supply chain management dari PBF terhadap proses pengadaan di Apotek Kimia Farma Unit Bisnis Sidoarjo dan memberikan rekomendasi terhadap performa supply chain management dari PBF. Rancangan penelitian ini dilakukan dengan mengikuti rancangan penelitian deskriptif non eksperimental dengan pengambilan data secara retrospektif. Kinerja supply chain PBF diukur dengan pendekatan Supply Chain Operations Reference (SCOR). Model hirarki awal disesuaikan dengan kondisi perusahaan. Normalisasi Snorm De Boer berfungsi untuk menyamakan nilai metrik yang digunakan sebagai indikator pengukuran. Aspek performa Supply Chain Management dari PBF di Apotek Kimia Farma Unit Bisnis Sidoarjo ditinjau dari atribut reliability diperolehan nilai sebesar 45,81 dan atribut responsiveness diperoleh nilai sebesar 15,24 atribut agility diperoleh nilai sebesar 14,40 atribut asset management sebesar 5,99. Secara total diperoleh jumlah skor performa PBF sebesar 81,44 dapat dikategorikan baik untuk sebuah sistem supply chain.
\end{abstract}

Kata kunci: Supply Chain Management (SCM); Supply Chain Operations Reference (SCOR); Pengadaan apotek; PBF

\begin{abstract}
Distribution of pharmacy supply chainmanagement performance evaluation to the procurement process at the Kimia Farma pharmacy Sidoarjo business unit. Based on the pharmaceutical care that emphasizes patient safety, the current pharmaceutical service paradigm has shifted from drug-oriented to patient-oriented. Among the factors to achieve patient safety is drugs availability that affected by the supply chain process from the distributor to the pharmacy. The purpose of this research was to find out how the performance of supply chain management from distributors to the procurement process at the Kimia Farma Pharmacy Sidoarjo Business Unit and provided the recommendations on supply chain management performance. This research applied a non-experimental descriptive design that the data collected with retrospective way. Distributor supply chain performance was measured by the Supply Chain Operations Reference (SCOR) approach. The initial hierarchical model was adapted to the conditions of the company. Normalization of Snorm De Boer used to equalize the metric values as measurement indicators. According to supply chain management from distributors at the Kimia Farma Pharmacy Sidoarjo Business Unit attribute gained a value of 45,81 in terms of Reliability, 15,24 in terms of Responsiveness, 14,40 in terms of Agility, and 5,99 in terms of Asset Management. PBF performance score was 81,44 totally. It might categorized as good for a supply chain system.
\end{abstract}


Keywords: Supply Chain Management (SCM); Supply Chain Operations Reference SCOR; distributor to the pharmacy

\section{Pendahuluan}

Pergeseran paradigma pelayanan kefarmasian dari pelayanan obat (drug oriented) menjadi lebih berfokus kepada pelayanan pasien (patient oriented) dengan berdasar kepada Pharmaceutical Care saat ini sedang terjadi. Fokus utama pelayanan kefarmasian yang tadinya pada pengelolaan obat bergeser menjadi pelayanan kesehatan kepada pasien yang bersifat komprehensif dengan perubahan tujuan utama untuk meningkatkan kualitas hidup pasien. Pelayanan kefarmasian tidak hanya dilakukan saat pasien telah menerima obat, namun diupayakan adanya pemantauan sampai saat pasien telah menggunakan obat tersebut (Kemenkes, 2016). Disini peran farmasis diharapkan untuk dapat turut serta dalam menjamin obat yang digunakan oleh pasien agar tepat dan sesuai dengan tujuan terapi. Dimulai dari proses pengadaan sampai pemantauan penggunaan. Dalam hal pengadaan, farmasis memiliki peranan dalam menjamin mutu obat. Farmasis harus dapat menentukan pemilihan distributor sebagai pemasok obat, selanjutnya pemantauan proses pemesanan dan penerimaan sampai dengan penyimpanan. Kualitas, mutu dan keaslian obat menjadi point utama dalam proses pengadaan obat. Faktor keamanan dan efektivitas menjadi prioritas yang harus dipenuhi guna menjamin patient safety. Upaya yang dilakukan oleh apotek untuk menjamin tercapainya tujuan terapi pengobatan pada pasien yaitu sarana pelayanan kefarmasian secara integral memiliki peran penting sebagai pendukung keberhasilan terapi melalui managemen obat dengan pemenuhan pesyaratan penyediaan logistik yang tepat waktu, tepat pasien, tepat produk, tepat penggunaan dan tepat jumlah atau dosis (Romero, 2013). Oleh karena itu, ketersediaan obat tidak lepas dari adanya pengaruh produsen dan distributor obat. Adanya keterkaitan secara menyeluruh dari seluruh elemen pendukung proses pengadaan, dalam hal ini kita sebut supply chain. Dimana supply chain sendiri menggambarkan suatu kesatuan jaringan yang tersusun atas beberapa organisasi yang terdiri dari produsen, distributor dan apotek yang saling terikat dan terlibat baik secara langsung maupun tidak langsung dengan tujuan untuk memenuhi permintaan pelanggan, dimana masing-masing perusahaan yang terlibat akan melakukan fungsi pengadaan material dilanjutkan proses transformasi material menjadi produk setengah jadi serta pada akhirnya menjadi produk jadi, kemudian distribusi produk jadi tersebut hingga ke end customer (Pujawan, 2017)

Supply Chain dan Supply Chain Management memiliki peran penting dalam efisiensi perusahaan. Hal ini perlu dilakukan karena akan dapat memberikan gambaran dari suatu distributor apakah perusahaan tersebut mampu untuk menyelaraskan antara permintaan dengan pemenuhan pasokan obat dengan tetap memperhatikan faktor efektifitas dan efisiensi. Langkah 
awal yang dapat dilakukan guna menuju perbaikan adalah dengan melakukan pengukuran dan penilaian terhadap performa supply chain. Indikator kinerja rantai pasok dapat diidentifikasi dengan menerapkan metode SCOR, sehingga dapat dijadikan bahan evaluasi dalam meningkatkan kinerja (Kurien, 2012; Ambe, 2014; Susanty, 2017). Evaluasi kinerja merupakan serangkaian proses pemberian bobot pada berbagai macam ukuran kinerja untuk mempresentasikan tingkat kepentingan dari setiap dimensi yang diukur (Council,2015). Nilai pengukuran kinerja dari PBF yang dapat diukur dalam performa Supply Chain Management, yaitu reliability (kehandalan), responsiveness (ketangggapan), flexibility / agility (respon) dan asset management (kekayaan) (Janvier-James, 2012). Penelitian ini dilakukan di Apotek Kimia Farma Unit Bisnis Sidoarjo dikarenakan saat ini pengembangan bisnis dan pelayanan di area ini berkembang cukup pesat dan luasnya area cakupan yang tersebar di 7 kota besar di Jawa Timur dimana tidak semua titik area apotek pelayanan terdapat PBF . Selain itu belum pernah dilakukannya analisa terhadap performa supply chain membuat perlunya penelitian ini dilakukan.

Adapun tujuan dilakukannya penelitian ini adalah untuk mengetahui bagaimana performa supply chain management dari PBF terhadap proses pengadaan di Apotek Kimia Farma Unit Bisnis Sidoarjo dan memberikan rekomendasi terhadap performa supply chain management dari PBF.

\section{Metode}

Dalam penelitian ini populasinya adalah semua Apoteker Pengelola Apotek di ruang lingkup area kerja di Apotek Kimia Farma Unit Bisnis Sidoarjo. Disamping itu populasi yang juga digunakan disini adalah seluruh PBF yang memberikan pelayanan pemenuhan kebutuhan obat di Apotek Kimia Farma Unit Bisnis Sidoarjo. Pada penelitian ini yang termasuk sampel adalah semua Apoteker Pengelola Apotek di ruang lingkup area kerja di Apotek Kimia Farma Unit Bisnis Sidoarjo. Sampel berikutnya adalah PBF yang kriterianya sudah ditetapkan oleh peneliti. Adapun kriteria adalah PBF termasuk sepuluh besar pemasok barang di Apotek Kmia Farma Unit Bisnis Sidoarjo dilihat dari total nominal pembelian, PBF yang memiliki legalitas dan perijinan lengkap

Metode rancangan penelitian deskriptif non eksperimental dengan pengambilan data secara retrospektif digunakan dalam penelitian ini. Data yang sudah diperoleh melalui penyebaran kuesioner dengan tujuan untuk menyesuaikan kegiatan pada rantai pasok distributor. Klasifikasi ini digunakan untuk mengidentifikasi matriks sebagai penyesuaian untuk membuat model hierarki SCOR pengukuran kinerja rantai pasok perusahaan. Kondisi perusahaan merupakan faktor yang harus diperhatikan sebagai matrik indikator dalam 
pengukuran kinerja penelitian, selanjutnya akan dilakukan proses analisis kinerja SCM berdasarkan pendekatan SCOR.

\subsection{Mengidentifikasi metrik tiap level}

Model SCOR digunakan sebagai rancangan untuk mengukur kinerja dengan mengidentifikasi metrik pada tiap levelnya. Pada level 1 terlihat proses SCM yang ada pada metode SCOR. Serangkaian proses tersebut terdiri dari plan (proses merencanakan), source (proses pengadaan bahan baku), make (proses produksi), deliver (proses pengiriman), dan return (proses pengembalian). Metrik level 2 merupakan dimensi untuk pengukuran kinerja SCM. Dimensi yang akan digunakan dalam penelitian ini antara lain dimensi Reliability (Kehandalan), Responsiveness (Ketangggapan), Flexibility (Respon), Cost (Biaya), dan Asset (Kekayaan). Metrik level 3 akan dilakukan identifikasi terhadap beberapa indikator yang memberikan pengaruh pada setiap tahapan proses dan dimensi SCM dari perusahaan itu. Hasil wawancara dan pengisian kuesioner indikator oleh responden menjadi dasar untuk menyusun hierarki pemilihan indikator kinerja SCM dan analisa terhadap ketiga level tersebut..

\subsection{Verifikasi Key Performance Indicator (KPI)}

Indikator - indikator kinerja SCM yang dirancang dapat diketahui kebenaran dan kesesuaiannya terhadap kebutuhan perusahaan dengan cara melakukan proses verifikasi. Tahapan verifikasi ini dapat dilakukan dengan mengecek indikator mana yang belum dicantumkan atau tidak perlu dicantumkan karena adanya kemungkinan terjadi kesamaan dengan indikator lain.

Nilai normalisasi (skor) tiap metrik dapat diperoleh dengan menggunakan proses normalisasi Snorm De Boer. Pada penelitian ini penyamaan skala nilai dilakukan dengan model interpolasi atau normalisasi. Bobot dari indikator-indikator akan dikonversikan ke dalam konversi nilai tertentu. Nilai tersebut berada dalam rentang yaitu antara 0 sampai 100. Nilai 0 diartikan memiliki kinerja paling buruk dan nilai 100 diartikan memiliki kinerja paling baik. Adapun rumus Snorm De Boer digunakan dalam penilaian normalisasi (Persamaan 1).

$$
\frac{(\mathrm{Si}-\mathrm{Smin})}{(\mathrm{Smax}-\mathrm{Smin})}=\frac{\text { skor }-0}{100-0}
$$

Persamaan 1. Perhitungan nilai normalisasi (skor) tiap metrik dengan metode normalisasi Snorm De Boer. Nilai indikator aktual yang berhasil dicapai ( $\mathrm{Si}$ ), nilai pencapaian performansi terburuk dari indikator kinerja (Smin) dan nilai pencapaian performansi terbaik dari indikator kinerja (Smax).

Model nilai normalisasi dilakukan untuk menyamakan skala nilai. Besaran bobot dari masing-masing indikator dikonversikan ke dalam konversi nilai tertentu yaitu antara 0 sampai 
100 (Tabel 1). Sehingga akan didapatkan parameter pada tiap indikator adalah sama, selanjutnya akan diperoleh data yang dapat dianalisa.

Tabel 1. Sistem monitoring indikator kinerja dengan model normalisasi. Sumber: Performance Measurement and Improvement Trienekens and Improvement in Supply Chain Hvolby, 2000 dalam sumiati, 2006).

\begin{tabular}{cc}
\hline Sistem monitoring & Indikator kinerja \\
\hline$<40$ & Sangat rendah \\
$40-50$ & Rendah \\
$50-70$ & Rata-rata \\
$70-90$ & Baik \\
$>90$ & Sangat baik \\
\hline
\end{tabular}

\subsection{Pembobotan dengan Analytical Hierarchy Process (AHP)}

Pembobotan nilai KPI dapat dilakukan dengan menggunakan model Analytical Hierarchy Process (AHP). Tingkat kepentingan dari masing-masing level dan besaran nilai KPI dapat diketahui dengan dilakukannya pembobotan. AHP sendiri merupakan salah satu jenis model pendukung dibuatnya keputusan (Saayt. TL, 1990). Dimana jenis model ini dapat memberikan penguraian permasalahan multi faktor yang bersifat kompleks menjadi suatu hirarki (Wibisono, 2006). Manfaat lain pada model ini adalah dapat melakukan penggabungan antara unsur objektif dengan subjektif terhadap suatu masalah. Beberapa langkah dasar penyusunan AHP terdiri dari 3 tahapan. Tahap awal yaitu desain dengan bentuk hirarki, yang perlu dilakukan pada model AHP sebagai langkah awal adalah menguraikan persoalan yang bersifat kompleks dan multikriteria selanjutnya menjadi bentuk hirarki. Tahap kedua adalah memprioritaskan prosedur, setelah proses pemecahan permasalahan telah tersusun menjadi sebuah struktur model hirarki, maka tahapan berikutnya adalah memilih mana prosedur yang bersifat prioritas untuk mendapatkan nilai relatif kemaknaan dari elemen penyusun di tiap level. Tahap ketiga adalahmelakukans perhitungan hasil, setelah terbentuk metriks preferensi, maka selanjutnya dapat dilakukan proses normalisasi dan menghitung bobot prioritas pada setiap metriksnya.

\subsection{Menghitung nilai total kinerja SCM}

Hasil perkalian dari nilai skor normalisasi tiap metrik dengan bobot metrik yang didapat dari hasil pembobotan menggunakan AHP merupakan nilai total kinerja SCM.

\section{Hasil dan Pembahasan}

Masing-masing atribut memiliki makna yang mewakili tiap dimensinya. Dimensi reliability memiliki 10 atribut pengukuran, dimensi responsiveness memiliki 5 atribut pengukuran, dimensi agility memiliki 4 atribut pengukuran dan dimensi asset management memiliki 3 atribut pengukuran. 


\subsection{Nilai normalisasi metriks SCOR model level 1}

Perhitungan data pada masing-masing performance attributes menggunakan persamaan Snorm De Boer (Tabel 2). Tabel 2 menunjukkan pada metriks perfect order fulfillment (POF) nilai maksimal diperoleh sebesar 100,00\%, nilai aktual yang dirasakan yaitu sebesar 92,63\%. Batas nilai minimal yang pernah dirasakan adalah $0 \%$. Nilai normalisasi setelah dilakukan perhitungan diperoleh angka sebesar 92,63\%. Disini masih terlihat adanya perbedaan antara nilai maksimal dengan nilai aktual, artinya bahwa masih ada permintaan yang belum dapat dipenuhi oleh PBF. Penelitian Luthfiana (2012) dengan studi kasus di PT. Indofarma menyatakan nilai POF sebesar 100\%. Sehingga dalam proses pengadaan dan pemesanan perlu adanya upaya dan perbaikan. Hal ini dapat terjadi biasanya dikarenakan stok barang di PBF mengalami kekosongan atau keterlambatan pengiriman barang dari produsen.

Tabel 2. Hasil perhitungan nilai normalisasi metriks SCOR model level 1 dari performence atributes yang telah dilakukan dengan menggunakan persamaan Snorm De Boer tehadap kinerja PBF di Apotek Kimia Farma Unit Bisnis Sidoarjo.

\begin{tabular}{lcccc}
\hline \multicolumn{1}{c}{ Metriks } & Maksimal & Aktual & Minimal & Normalisasi \\
\hline Perfect order fulfillment (\%) & 100,00 & 92,63 & 0 & 92,63 \\
Order fulfillment cycle time (hari) & 2,60 & 4,00 & 7,40 & 70,83 \\
Supply chain flexibility/ adaptability & 100,00 & 89,30 & 0 & 89,30 \\
(\%) & 30,00 & 45,00 & 58,00 & 46,43 \\
Cash to cash cycle time (hari) & & & & \\
\hline
\end{tabular}

\subsection{Hasil Nilai Performa}

Selanjutnya dilakukan perhitungan hasil perolehan nilai performa dengan tujuan untuk memberikan gambaran baik atau buruknya performa dari suatu PBF. Pengukuran nilai ini merupakan langkah awal untuk melakukan perbaikan terhadap performa kinerja perusahaan. Pada tabel 3 dapat diketahui bahwa nilai hasil akhir performa supply chain dari PBF sebesar 81,44 dengan nilai tertinggi pada skor performa untuk atribut reliability sebesar 45,81 . Ini bermakna bahwa PBF terkait memiliki performa nilai kehandalan yang baik. Kemampuan untuk dapat melakukan pemenuhan atas permintaan barang tergolong baik. Sedangkan nilai terendah didapat pada atribut asset management dengan metrik cash to cash cycle time skor perolehan sebesar 5,99. Perolehan penilaian tersebut bermakna bahwa performa PBF dalam hal kemampuan serta kecepatan dalam mengubah persediaan menjadi uang masih belum optimal. Beberapa hal yang mempengaruhi nilai tersebut diantaranya ketersediaan barang di PBF tersebut, kompetisi dengan PBF lain dan dampak perubahan regulasi pemerintah mengenai kebijakan pelayanan kesehatan Jaminan Kesehatan Nasional.

Perolehan nilai berdasarkan sistem monitoring indikator performa sebesar 81,44 dapat dikategorikan baik berdasarkan sistem monitoring indikator kinerja untuk sebuah sistem supply chain dari suatu perusahaan. Namun masih perlu terus dilakukan monitoring dan evaluasi 
terhadap indikator performa untuk meningkatkan nilai performa yang diperoleh. Penelitian (Wahyuniardi, 2017) dengan studi kasus di PT. Brodo Ganesha Indonesia memberikan hasil total skor performa supply chain sebesar 59,21. Hal ini menunjukkan hasil perhitungan nilai akhir performa atribut total keseluruhan PBF lebih baik. Hasil penelitian (Kurnia, 2017) menunjukkan bahwa pelaksanaan SCM secara tidak langsung memberikan pengaruh positif yang signifikan terhadap kinerja perusahaan.

Tabel 3. Hasil perhitungan skor nilai akhir performence atributes nilai total keseluruhan PBF di Apotek Kimia Farma Unit Bisnis Sidoarjo

\begin{tabular}{llrrr}
\hline $\begin{array}{l}\text { Performance } \\
\text { Attributes }\end{array}$ & \multicolumn{1}{c}{ Metrik } & Normal & Bobot & \multicolumn{1}{c}{ Skor } \\
\hline Reliability & Perfect order fulfillment (\%) & 92,63 & 0,50 & 45,81 \\
Responsiveness & Order fulfillment cycle time (hari) & 70,83 & 0,21 & 15,24 \\
Agility & Supply chain flexibility/ adaptability (\%) & 89,30 & 0,16 & 14,40 \\
Asset & Cash to cash cycle time (hari) & 46,43 & 0,13 & 5,99 \\
management & & & & $\mathbf{8 1 , 4 4}$ \\
\hline \hline Jumlah skor performa supply chain
\end{tabular}

\subsection{Rekap Nilai Performa PBF}

Penilaian performa dari masing-masing PBF akan memberikan gambaran terhadap kinerja suatu perusahaan. Nilai tersebut tersusun oleh beberapa atribut, dengan mengetahui nilai pada masing-masing atribut pendukungnya maka proses perbaikan kinerja dapat dilakukan dengan lebih terfokus. Pada tabel 4 terlihat nilai dari atribut dan nilai performa dari masing-masing PBF dengan besaran perolehan nilai yang beragam. Nilai tersebut menunjukkan kinerja dari masing-masing PBF. Pada atribut reliability PBF yang memiliki nilai tertinggi dari keseluruhan sampel menggambarkan bahwa kinerja dari PBF tersebut mampu memberikan pelayanan dalam pemenuhan permintaan dengan sangat baik. Sedangkan PBF dengan nilai rendah bermakna bahwa dalam pemenuhan pemesanan oleh pihak apotek masih perlu banyak perbaikan baik itu dari sistem/alur pelayanan pemenuhan permintaan ataupun dari permasalahan lain. Persaingan antar perusahaan dapat diatasi dengan menyusun rencana strategis. Salah satunya adalah perlunya sifat agility dan adaptability dari perusahaan tersebut sehingga pada akhirnya dapat meningkatkan performanya (Rahmasari, 2016).

Atribut responsiveness menunjukkan perolehan nilai yang berbeda pula antar sampel. Terlihat bahwa antara nilai tertinggi dengan yang terendah ada perbedaan atau rentang yang sangat besar. Sehingga dirasa perlu untuk melakukan kajian lebih kanjut terhadap PBF yang memiliki nilai lebih rendah. Hal ini terjadi karena kemampuan finansial dan dukungan pemilik modal dalam mengembangkan usaha masing-masing PBF berbeda-beda.

Pada atribut Agility nilai yang tertinggi diperoleh PBF yang mampu melekukan respon atau tanggap dengan cepat dalam menyikapi atau menerima permintaan diluar kebiasaan/ 
regular. Hal ini bisa terjadi karena masing-masing PBF memiliki target dalam penjualan. Sehingga segala hal dilakukanuntuk mencapai target penjualan perbulan.

Tabel 4. Hasil rekap perhitungan nilai performence atributes masing- masing PBF di Apotek Kimia Farma Unit Bisnis Sidoarjo

\begin{tabular}{lcccc}
\hline PBF & Reliability & Responsiveness & Agility & Asset Management \\
\hline KFTD & 93.29 & 0.83 & 93.00 & 14.29 \\
APL & 98.78 & 0.33 & 90.00 & 25.00 \\
BSP & 97.45 & 0.75 & 93.00 & 14.29 \\
AAM & 90.03 & 0.60 & 88.00 & 100.00 \\
AMS & 86.04 & 0.67 & 92.00 & 100.00 \\
PPG & 84.81 & 0.67 & 90.00 & 50.00 \\
TEMPO & 94.42 & 0.86 & 81.00 & 50.00 \\
MARGA & 92.90 & 0.60 & 90.00 & 50.00 \\
KALISTA & 93.80 & 0.86 & 86.00 & 100.00 \\
BLESSINDO & 94.78 & 0.60 & 90.00 & 14.29 \\
\hline
\end{tabular}

Atribut Asset Management pada masing-masing PBF juga berbeda. PBF yang memiliki nilai tertinggi menggambarkan bahwa pengelolaan baik itu asset maupun keuangan sudah dilakukan dengan baik. Untuk PBF dengan nilai terendah maka perlu dilakukan perbaikan semisal dengan melakukan pencatatan lebih tertib terhadap jatuh tempo pembayaran, dan pengaturan pembayaran.

\subsection{Nilai akhir pembobotan masing-masing atribut}

Hasil nilai akhir dari tiap atribut akan memberikan gambaran perbedaan performa kinerja pada masing-masing PBF di tiap atribut yang diteliti. Perbaikan performa kinerja akan dapat dilakukan dengan berdasar pada hasil penilaian ini. Pada tabel 5 dilakukan perhitungan dari masing-masing atribut pada tiap PBF dengan mengalikan perolehan nilai normalisasi dengan masing-masing bobotnya. Sehingga dari sini akan diperoleh nilai akhir, yang dapat memberikan gambaran terhadap performa kinerja setiap PBF yang diteliti.

Terlihat pada masing-masing atribut terdapat nilai akhir yang berbeda-beda. Pada atribut Reliability terlihat bahwa nilai terbesar diperoleh hanya satu PBF, disini dapat menggambarkan bahwa kinerja PBF tersebut dalam upaya pelayanan pemenuhan permintaan oleh pihak apotek dalam proses pengadaan dapat dikategorikan baik. Hal ini ditunjang oleh sistem manajemen dari PBF tersebut yang sudah terstruktur dengan rapi. Selain itu ketepatan dalam pengiriman, pada PBF ini didukung oleh armada layanan antar yang banyak sehingga mempercepat proses pengiriman.

Pada atribut responsiveness nilai tertinggi diperoleh oleh tiga PBF, hal ini bermakna bahwa pada ketiga PBF tersebut kecepatan dalam pengiriman pemesanan lebih baik bila dibandingkan dengan PBF yang lain. Dengan demikian maka ketersediaan stok barang dapat terjaga, dan dapat meminimalkan terjadinya penolakan permintaan oleh pasien. Untuk atribut 
agility nilai tertinggi diperoleh sebanyak dua PBF. Hal ini menggambarkan bahwa dari kesepuluh sampel, hanya dua PBF yang mampu memenuhi permintaan diluar kebutuhan regular atau biasanya. Kemampuan dalam pemenuhan permintaan apotek dengan jumlah yang bervarian, hal ini dapat terjadi karena adanya permintaan mendadak dalam jumlah banyak karena adanya Kondisi Luar Biasa (KLB) atau ada wabah penyakit.

Tabel 5. Hasil perhitungan nilai akhir masing- masing PBF pada tiap performence atributes di Apotek Kimia Farma Unit Bisnis Sidoarjo

\begin{tabular}{|c|c|c|c|c|}
\hline $\begin{array}{l}\text { Performa } \\
\text { Atributes }\end{array}$ & Nama PBF & Normalisasi & Bobot & Nilai Akhir \\
\hline \multirow{10}{*}{ Reliability } & KFTD & 93,29 & 0,49 & 46,14 \\
\hline & APL & 98,78 & 0,49 & 48,86 \\
\hline & BSP & 97,45 & 0,49 & 48,20 \\
\hline & AAM & 90,03 & 0,49 & 44,53 \\
\hline & AMS & 86,04 & 0,49 & 42,56 \\
\hline & PPG & 84,81 & 0,49 & 41,95 \\
\hline & TEMPO & 94,42 & 0,49 & 46,70 \\
\hline & MARGA & 92,90 & 0,49 & 45,95 \\
\hline & KALISTA & 93,80 & 0,49 & 46,39 \\
\hline & BLESSINDO & 94,78 & 0,49 & 46,88 \\
\hline \multirow{9}{*}{ Responsiveness } & KFTD & 0,83 & 0,22 & 0,18 \\
\hline & APL & 0,33 & 0,22 & 0,07 \\
\hline & BSP & 0,75 & 0,22 & 0,16 \\
\hline & AAM & 0,60 & 0,22 & 0,13 \\
\hline & AMS & 0,67 & 0,22 & 0,14 \\
\hline & PPG & 0,67 & 0,22 & 0,14 \\
\hline & TEMPO & 0,86 & 0,22 & 0,18 \\
\hline & MARGA & 0,60 & 0,22 & 0,13 \\
\hline & KALISTA & 0,86 & 0,22 & 0,18 \\
\hline \multirow{11}{*}{ Agility } & BLESSINDO & 0,60 & 0,22 & 0,13 \\
\hline & KFTD & 93,00 & 0,16 & 15,00 \\
\hline & APL & 90,00 & 0,16 & 14,52 \\
\hline & BSP & 93,00 & 0,16 & 15,00 \\
\hline & AAM & 88,00 & 0,16 & 14,19 \\
\hline & AMS & 92,00 & 0,16 & 14,84 \\
\hline & PPG & 90,00 & 0,16 & 14,52 \\
\hline & TEMPO & 81,00 & 0,16 & 13,07 \\
\hline & MARGA & 90,00 & 0,16 & 14,52 \\
\hline & KALISTA & 86,00 & 0,16 & 13,87 \\
\hline & BLESSINDO & 90,00 & 0,16 & 14,52 \\
\hline \multirow{10}{*}{$\begin{array}{l}\text { Asset } \\
\text { Management }\end{array}$} & KFTD & 14,29 & 0,13 & 1,84 \\
\hline & APL & 25,00 & 0,13 & 3.23 \\
\hline & BSP & 14,29 & 0,13 & 1,84 \\
\hline & AAM & 100,00 & 0,13 & 12,90 \\
\hline & AMS & 100,00 & 0,13 & 12,90 \\
\hline & PPG & 100,00 & 0,13 & 6,45 \\
\hline & TEMPO & 50,00 & 0,13 & 6.45 \\
\hline & MARGA & 50,00 & 0,13 & 6.45 \\
\hline & KALISTA & 50,00 & 0,13 & 12,90 \\
\hline & BLESSINDO & 100,00 & 0,13 & 1,84 \\
\hline
\end{tabular}


Sedangkan untuk atribut asset management nilai tertinggi dicapai oleh tiga PBF. Pencapaian angka ini menunjukkan bahwa ketiga PBF tersebut sudah mampu melakukan pengelolaan dan perbaikan dalam managemennya. Terutama dalam hal pengelolaan inventory dan pembayaran tagihan. Sedangkan untuk PBF dengan nilai rendah, perlu dilakukan perbaikan dalam pencatatan dan pengaturan pembayaran serta perlu adanya perbaikan inventory yang bisa dibantu dengan alat atau program komputerisasi

\subsection{Nilai Total Skor Performa}

Dengan menghitung nilai total skor performa kinerja dari PBF yang diteliti dari hasil penjumlahan kinerja masing-masing atribut maka dapat diketahui mana PBF yang dapat memberikan dan menunjukkan kinerja terendah sampai yang terbaik. Hal ini berguna untuk melakukan analisa kinerja dari masing-masing PBF dan juga memberikan bahan analisa penentuan kebijakan dari penerima kinerja PBF tersebut. Manfaat lainnya adalah evaluasi untuk meningkatkan daya saing dan loyalitas konsumen (Wigaringtyas, 2013). Nilai akhir dari tiap atribut akan memberikan gambaran perbedaan performa kinerja pada masing-masing PBF di tiap atribut yang diteliti. Perbaikan performa kinerja akan dapat dilakukan dengan berdasar pada hasil penilaian ini.

Tabel 6. Hasil rekap perhitungan nilai performence atributes secara total dari masing- masing PBF di Apotek Kimia Farma Unit Bisnis Sidoarjo

\begin{tabular}{lccccc}
\hline Nama PBF & Reliability & Responsiveness & Agility & Asset Management & Total \\
\hline KFTD & 46,14 & 0,18 & 15,00 & 1,84 & 63,16 \\
APL & 48,86 & 0,07 & 14,52 & 3,23 & 66,67 \\
BSP & 48,20 & 0,16 & 15,00 & 1,84 & 65,20 \\
AAM & 44,53 & 0,13 & 14,19 & 12,90 & 71,75 \\
AMS & 42,56 & 0,14 & 14,84 & 12,90 & 70,44 \\
PPG & 41,95 & 0,14 & 14,52 & 6,45 & 63,06 \\
TEMPO & 46,70 & 0,18 & 13,07 & 6,45 & 66,40 \\
MARGA & 45,95 & 0,13 & 14,52 & 6,45 & 67,04 \\
KALISTA & 46,39 & 0,18 & 13,87 & 12,90 & 73,35 \\
BLESSINDO & 46,88 & 0,13 & 14,52 & 1,84 & 63,37 \\
\hline
\end{tabular}

Tabel 6 merupakan hasil rekap perolehan perhitungan total skor performa dari masingmasing PBF. Total nilai performa menunjukkan adanya perbedaan antara PBF satu dengan yang lainnya. Angka total terbesar menunjukkan kinerja PBF tersebut baik dengan masing-masing atribut pendukungnya. Nilai tertinggi yang diperoleh PBF dalam total skornya ada kalanya tidak didukung oleh perolehan nilai maksimal pada setiap atributnya. Hasil penelitian menunjukkan bahwa PBF yang memperoleh nilai tertinggi memiliki satu aspek yang nilai perolehanya masih dibawah PBF lain. Namun pada atribut lain, nilai yang diperoleh sangat tinggi sehingga mengakibatkan nilai total menjadi terbesar. Hal ini menunjukkan bahwa meskipun PBF tersebut memperoleh angka total terbesar, masih perlu adanya perbaikan pada aspek tertentu guna 
mendapatkan performa yang lebih baik lagi. Beberapa hal yang mempengaruhi perencanaan supply chain management secara mendasar antara lain perubahan teknologi, lingkungan bisnis, kompetensi dan akuisisi (Suryani, 2011).

Tabel 7. Hasil perhitungan total skor akhir dari semua komponen performence atributes terhadap masing- masing PBF di Apotek Kimia Farma Unit Bisnis Sidoarjo

\begin{tabular}{lll}
\hline No & Nama PBF & Total Skor \\
\hline 1 & KALISTA & 73.35 \\
2 & AAM & 71.75 \\
3 & AMS & 70.44 \\
4 & MARGA & 67.04 \\
5 & APL & 66.67 \\
6 & TEMPO & 66.40 \\
7 & BSP & 65.20 \\
8 & BLESSINDO & 63.37 \\
9 & KFTD & 63.16 \\
10 & PPG & 63.06 \\
\hline
\end{tabular}

\subsection{Rating Akhir Nilai Skor Performa}

Dari keseluruhan perhitungan diatas akan memberikan perolehan nilai skor akhir bagi masing-masing PBF yang diteliti. Peringkat tertinggi sampai terendah dari masing-masing PBF akan dapat terlihat. Dengan menghitung nilai total skor performa kinerja dari PBF yang diteliti maka dapat digunakan untuk melakukan analisa kinerja dari masing-masing PBF. Tabel 7 menunjukkan urutan penilaian dari kesepuluh sampel PBF yang diambil. Urutan berdasarkan dari perolehan nilai akhir tertinggi sampai ke yang terendah. Beberapa strategi yang dapat diambil dalam mengupayak perbaikan pada masing-masing atribut penunjang nilai akhir. Dimulai dari setiap proses yang berkaitan dengan pemasok, aktivitas produksi dan distribusi hingga produk sampai ketangan konsumen (Huan, 2004). Pada atribut reliability beberapa langkah yang dapat diambil antara lain melakukan peningkatan koordinasi antara PBF dengan apotek sebagai pelanggan. Hal ini dapat dilakukan dengan menentukan target dan menjadwalkan pertemuan dengan pelanggan secara rutin. Sehingga dapat dilakukan pemecahan permasalahan yang terjadi antara PBF dan apotek sebagai pelanggan bila ada kendala dalam proses pemesanan. Kerjasama dan tumbuhnya rasa kepercayaan serta pengakuan merupakan titik fokus pengelolaan manajemen supply chain, bila semua proses dapat dilakukan pengelolaan dengan baik maka secara keseluruhan akan memberikan hasil yang lebih besar dari jumlah bagian penyusunnya (Christopher, 2011). Kepuasan konsumen berbanding lurus dengan kinerja yang baik, sehingga diperlukan adanya pengukuran kinerja untuk mengetahui nilai saat ini dan upaya untuk terus meningkatkannya (Liputra, 2018). 


\section{Kesimpulan}

Performa Supply Chain Management dari PBF di Apotek Kimia Farma Unit Bisnis Sidoarjo ditinjau dari atribut penelitian secara total diperoleh jumlah skor sebesar 81,44 dapat dikategorikan masuk rentang baik untuk sistem supply chain dari suatu perusahaan. Rekomendasi yang diberikan terhadap performa Supply Chain Management dari PBF di Apotek Kimia Farma Unit Bisnis Sidoarjo yaitu perlu adanya perbaikan terutama pada dimensi asset management berupa strategi pencatatan pembukuan yang berisikan waktu pembayaran dan pembuatan penilaian (key performa indicator) pada atribut cash to cash cycle time.

\section{Ucapan Terima Kasih}

Penulis ucapkan terima kasih kepada Manajemen PT. Kimia Farma Apotek Unit Bisnis Sidoarjo, Universitas Setia Budi, yang membantu didalam pengumpulan data pengerjaan hingga mendapatkan hasil penelitian.

\section{Deklarasi Konflik Kepentingan}

Semua penulis menyatakan tidak ada konflik kepentingan terhadap naskah ini.

\section{Daftar Pustaka}

Ambe, JM. (2014). Key indicators for optimizing SC performance: The case of light vehicle manufactures in South Africa. The Journal of Applied Business Reseaerch, Vol.30 (1), pp 277-290.

Christopher, M. (2011). Logistics and Supply Chain Management: Strategies for Reducing Cost and Improving Service Financial Times: Pitman Publishing. London, 1998 ISBN 0273 630490 (hardback) 294+ 1Xpp. Taylor \& Francis

Council, A.S.C. (2015). SCOR Quick Reference Guide. Versión 10.0 Recuperado Httpwww Apics Orgdocs default - Sourcescc-Non research apicsscc scor quick reference guide Pdf

Huan, S.H., Sheoran, S.K. and Wang, G. (2004). A review and analysis of supply chain operations reference (SCOR) model. Supply Chain Management: An International Journal, 9(1), pp.23-29

Janvier-James, A.M. (2012). A new introduction to supply chains and supply chain management: Definitions and theories perspective. Int. Bus. Res. 5, 194-207

Kemenkes. (2016). Peraturan Menteri Kesehatan Republik Indonesia Nomor 35 Tahun 2016 Tentang Standar Pelayanan Kefarmasian Di Apotek. Jkt. Dep. Kesehat. RI.

Kurien, G.P.; Qureshi, M.N. (2012). Performance measurement systems for green SCs using modified balanced score card and analytical hierarchical process. Scientific Research and Essays, 7(36), pp.: $3149-3161$

Kurnia, E. (2017). Pengaruh Praktik Supply Chain Management (SCM) Terhadap Kinerja Perusahaan dan Keunggulan Bersaing pada UKM Olahan Makanan Bika Ubi BARKAH di Kota Medan. 
Liputra, D.T., Santoso, S. and Susanto, N.A. (2018). Pengukuran Kinerja Rantai Pasok Dengan Model Supply Chain Operations Reference (SCOR) dan Metode Perbandingan Berpasangan. Jurnal Rekayasa Sistem Industri, 7(2), pp.119-125.

Luthfiana, A.C., Perdana, R. and Kalijaga, T.I.U.S. (2012). Pengukuran Performansi Supply Chain Dengan Pendekatan Supply Chain Operation Reference (SCOR) dan Analytical Hierarchy Process (AHP) Studi Kasus: PT. Indofarma Global Medika. Indofarma Global Medika. Perpustakaan UIN Sunan Kalijaga

Pujawan, I.N. dan ER, M. (2017). Supply Chain Management Edisi Ketiga. Surabaya: Guna Widya

Rahmasari, L. (2016). Pengaruh supply chain management terhadap kinerja perusahaan dan keunggulan bersaing (Studi kasus pada industri kreatif di Provinsi Jawa Tengah). Majalah Ilmiah INFORMATIKA, 2(3).

Romero, A. (2013). Managing medicines in the hospital pharmacy: logistics inefficiencies, in: Proceedings of the World Congress on Engineering and Computer Science. pp. 1-6.

Saaty, T.L. (1990). The Analytical Hierarchy Process: Planning, Priority Setting Resource Allocation. Pittsburgh University Pers. P. 97

Sumiati,2006. Pengukuran Performansi Supply Chain Perusahaan dengan pendekatan Supply Chain Operation Refrence (SCOR) di PT. Madura Guano Industri (KAMALMADURA). Fakultas Teknologi Industri : UPN Veteran Jawa Timur

Suryani, E. (2011). Analisis faktor kritis keberhasilan pada implementasi e-procurement. ComTech: Computer, Mathematics and Engineering Applications, 2(2), pp.1164-1171

Susanty, A.; Santosa, H.; Tania, F. (2017). "Penilaian implementasi Green Supply Chain Management di UKM Batik Pekalongan dengan Pendekatan GreenSCOR”. Jurnal Ilmiah Teknik Industri, Vol.16 (1), pp.: 55 - 63.

Wahyuniardi, R., Syarwani, M. and Anggani, R., 2017. Pengukuran Kinerja Supply Chain Dengan Pendekatan Supply Chain Operation References (SCOR). Jurnal Ilmiah Teknik Industri, 16(2), pp.123-132.

Wibisono, Dermawan. (2006). Manajemen Kinerja. Penerbit Erlangga : Jakarta

Wigaringtyas, L.D. (2013). Pengukuran Kinerja Supply Chain Management Dengan Pendekatan Supply Chain Operation Reference (SCOR). Jurusan Teknik Industri Universitas Muhammadiyah Surakarta.

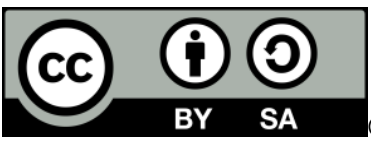

2021 by the authors. Submitted for possible open access publication under the terms and conditions of the Creative Commons Attribution-ShareAlike 4.0 International (CC BY-SA 4.0) license (https://creativecommons.org/licenses/by-sa/4.0/). 